\title{
Severe COVID-19 is Caused by an Overreacting Immune System: Highly Dosed Corticosteroids Could be a Lifesaver!
}

\author{
Jan Eize Siegersma
}

Retired

Corona Virus Disease-19 (COVID-19) is caused by Severe Acute Respiratory Syndrome Coronavirus 2 (SARS-CoV-2), formerly called Novel Coronavirus (2019-nCoV). The virus is causing the biggest pandemia since the Spanish Flu about a century ago. Half a year after the first outbreak in Wuhan (China) there have been almost 10 million confirmed cases and the death toll is almost half a million. ${ }^{[1]}$ How to treat the disease in the best way is still unclear. I present a novel hypothesis about the pathogenesis of the severe form of COVID-19. I will suggest a treatment too, which might be lifesaver.

Most people with COVID-19 develop only mild symptoms. Some however develop life threatening complications. This can also happen to young, previously healthy persons. Those serious complications start suddenly after a few days of mild symptoms. The hallmark of those severe complications is inflammation. Severe inflammation of the lungs, kidneys, heart, skin and blood system (thromboembolism, arteritis) causing multiple organ failure has been described. The mortality among those patients is high. ${ }^{[2-4]}$

Please cite this article as: Siegersma JE. Severe COVID-19 is Caused by an Overreacting Immune System: Highly Dosed Corticosteroids Could be a Lifesaver! Anatol J Family Med 2021;4(1):106-107.

Address for correspondence: Dr. Jan Eize Siegersma. Retired, Netherlands.

E-mail:

eizesmail@hotmail.com

Received Date: 02.07.2020 Accepted Date: 08.09.2020 Published online: 10.03.2021

OCopyright 2021 by Anatolian Journal of Family Medicine Available online at www.anatoljfm.org OPEN ACCESS

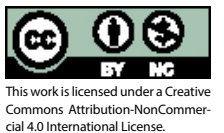

My hypothesis is that in the case of severe COVID-19, the immune system gets triggered by the virus. This happens during the initial period with mild symptoms. After being triggered the immune system gives a non-functional over response causing massive inflammation. This reminds me of severe autoimmune diseases like systemic lupus erythematosus (SLE). Active SLE can also give a very severe immune response resulting in severe multiple organ inflammation similar to severe COVID-19. SLE can also be triggered by a virus. ${ }^{[5]}$ This being said I think we should treat severe COVID-19 and severe SLE in the same way, i.e. using high dose corticosteroids.

Glucocorticosteroids, like prednisolone and dexamethasone, are very potent inhibitors of the inflammation response. Those drugs have been available for decades. The effects and side effects are well known. They are cheap and widely available. At this moment, the World Health Organization does not recommend the use of corticosteroids for COVID-19, beyond the scope of clinical trails. ${ }^{[6]}$ As a coincidence, the University of Oxford (United Kingdom) has recently presented the results of a study. In patients with COVID-19, low dose dexamethasone was compared with placebo. ${ }^{[7]}$ At the time of writing this article, the results have not yet been published in a peer-reviewed scientific journal, but have been accepted for publication. ${ }^{[8]}$ Low dose dexamethasone (6 mg daily orally or intravenously) should have given a reduction in mortality of patients with severe COVID-19 by $1 / 3 \cdot \cdot^{[7,8]}$ This is a great result! It will likely change clinical practice. But it does not really surprise me. It confirms me that the 
real problem is the overreacting immune system and that giving corticosteroids helps. I think that low dose corticosteroids will make a difference. But I expect that severely ill patients with COVID-19 will benefit even more from high dose corticosteroids.

COVID-19 is not one disease. Maybe there are two diseases caused by the same virus. At least COVID-19 has two faces. At one site of the spectrum we have patients with only mild or no symptoms. At the other site we have patients dying of pneumonia and/or multiple organ failure because of a massive inflammatory response. My hypothesis is that the severe form of COVID-19 is caused by an overreaction of the immune system triggered by the virus. Maybe the severe form of COVID-19 has even to be considered as a kind of (auto) immune disease. There are similarities in the symptoms of severe COVID-19 and severe immune diseases like SLE. ${ }^{[9]}$ Severe SLE is treated with high dose corticosteroids. ${ }^{[10]}$ I think there is a role for corticosteroids in the treatment of COVID-19. The results from "Oxford" support me in this idea. ${ }^{[7,8]}$ For the best treatment for the less severe patients, we should maybe wait for the results of clinical trails. But we cannot wait for the severe patients. ${ }^{[2-4,9,10]}$ Those people are dying. I suggest to treat severe COVID-19 like severe SLE using high dose corticosteroids intravenously for several days. Methylprednisolone intravenously $1000 \mathrm{mg}$ daily for 3-5 days could probably be a lifesaver!

\section{REFERENCES}

1. Johns Hopkins University \& Medicine. Coronavirus Resource Center. Available at: https://coronavirus.jhu.edu/ map.html. Accessed Oct 27, 2020.

2. Zaim S, Chong JH, Sankaranarayanan V, Harky A. COVID-19 and multiorgan response. Curr Probl Cardiol 2020;45(8):100618. [CrossRef]

3. Bikdeli B, Madhavan MV, Jimenez D, Chuich T, Dreyfus I, Driggin $\mathrm{E}_{\text {; }}$ Global COVID-19 Thrombosis Collaborative
Group, Endorsed by the ISTH, NATF, ESVM, and the IUA, Supported by the ESC Working Group on Pulmonary Circulation and Right Ventricular Function. COVID-19 and thrombotic or thromboembolic disease: implications for prevention, antithrombotic therapy, and follow-up: JACC state-of-the-art review. J Am Coll Cardiol 2020;75(23):2950-73. [CrossRef]

4. Jones VG, Mills M, Suarez D, Hogan CA, Yeh D, Segal JB, et al. COVID-19 and Kawasaki disease: novel virus and novel case. Hosp Pediatr 2020;10(6):537-40. [CrossRef]

5. Nelson $P$, Rylance $P$, Roden $D$, Trela $M$, Tugnet N. Viruses as potential pathogenic agents in systemic lupus erythematosus. Lupus 2014;23(6):596-605. [CrossRef]

6. WHO. Clinical management of COVID-19. Interim guidance. 27 May 2020. Available at: https://www.who.int/ publications/i/item/clinical-management-of-covid-19. Accessed May 27, 2020.

7. University of Oxford. News and events. Dexamethasone reduces death in hospitalised patients with severe respiratory complications of COVID-19. Available at: http:// unw.oxacuk/news/2020-06-16-dexamethasonereduces-death-hospitalised-patients-severe-respiratory-complications. Accessed June 16, 2020.

8. RECOVERY Collaborative Group, Horby P, Lim WS, Emberson JR, Mafham M, Bell JL, et al. Dexamethasone in hospitalized patients with Covid-19- Preliminary report. N Engl J Med. 2020 Jul 17. doi: 10.1056/NEJMoa2021436. [Epub ahead of print]. [CrossRef]

9. Dall'Era M, Wofsy D. Clinical Manifestations of Systemic Lupus Erythematosus. Firestein GS, Budd RC, Gabriel SE, Maclnnes IB, O'Dell JR, eds. Kelley and Firestein's Textbook of Rheumatology. 10th ed. Philadelphia, Pa: Elsevier Saunders; 2017. 1345-67. [CrossRef]

10. Chowdhary VR. Broad Concepts in Management of Systemic Lupus Erythematosus. Mayo Clin Proc. 2017 May;92(5):744-761. [CrossRef] 